\title{
Legal Protection of the Rights of the Child Victims in Indonesian Juvenile Criminal Justice System
}

\author{
Oksidelfa Yanto (a), Yoyon M. Darusman (b), Susanto (c), Aria Dimas Harapan (d)
}

Page | 24

(a) (b) (c) (d) Magister Law Science of University of Pamulang, dosen00240@ unpam.ac.id

\begin{abstract}
This research purposes to observe the development of crimes against children in Indonesia. Firstly, will take a closer look toward the importance of child protection in family, school and the environment from violence and crime. Secondly, will evaluate how far the criminal justice system can give protection toward the children as victims of violence and crime. Thirdly, looking at the state responsibility in giving sanctions through the criminal justice system. The method used in this research is juridical-normative by collecting secondary data related to legislation and materials obtained from books, journals, and other relevant materials. The observation result shown that many children are victims of violence. The victimization is basically everywhere, not only at home, but also at school. Violence in schools is not merely physical violence, but also psychological. The responsibility for protecting, educating, and developing children lies in the environment, family, and school. The function of criminal law to fight crimes against children's rights is a major factor in the success of the juvenile criminal justice system.
\end{abstract}

Keywords: Children's rights; crime; criminal justice

\section{Overview}

Indonesia is a developing country. For the future of Indonesia toward advanced country to be accomplished, it is necessary for the state to protect and provide protection to every citizen, especially the protection of children. Children is the country's next generation and the main capital of families, and nations. This protection toward them is important because children cannot protect their rights by themselves. Many parties who are having powerful influence their lives in potentially negative manner, thus the state and society must strive for the protection of children's rights (Prakoso, 2016).

Moreover, the Indonesian people already have a commitment to protect children, especially when commemorating National Children's Day every July 23. Even in the commemoration of the children's day the Indonesian Child Protection Commission (KPAI) stated that child protection needs special handling so that the fulfillment of children's basic rights and protection from violence, discrimination and exploitation are part of the mental revolution process. In various cases, there are still many children who are victims of crime. Even the crimes that afflict children are not only physical violence, sexual abuse but also the loss of a child's life. In holy Qur'an, it is explained that it is not permissible for someone to eliminate the lives of others, let alone the lives of children. It is mentioned "So whoever kills one human being without error then he is like killing a whole human being and whoever revives it is like reviving all humans (Q. Al-Maidah, 32).

Crimes against children leave deep wounds for all parties. Even the wound has lowered the dignity of the family of the child. In fact, based on their dignity, everyone needs legal 
Jurnal Yustika

Vol. 23 No. 01, Jul 2020

Page | 25

Legal Protection of the Rights of the Child Victims in Indonesian Juvenile Criminal Justice System

Oksidelfa Yanto Yoyon M Darusman Susanto Aria Dimas Harapan protection regarding their physical, life, freedom and feelings or peace of heart. Obtaining legal protection in its essence is the right of every citizen. This is in line with the purpose of the law, namely the existence of benefits in the form of physical and life protection.

Protecting the legal interests of children, all components of the nation reinforce the commitment that their children must be protected by their rights. Indonesia already has a child protection law. The law can be applied to impose sanctions on perpetrators of crimes against children. This is in accordance with the principle of legality that is owned by Indonesian criminal law. The principle of legality explains that no action can be punished unless there are legal or statutory rules that govern it first. If there are rules governing, now how are the rules implemented to punish perpetrators of crimes against children.

Protection of children becomes a fixed price that can no longer be negotiated. Severe sanctions can be applied to anyone who commits a crime against a child. Even the international community has also committed to making rules regarding child protection. These rules are shaded by the United Nations (UN) in the Convention on the Rights of the Child. In the UN Convention, the rights of children are given great attention, where the United Nations highly upholds the dignity and inherent dignity of children. Children must grow and develop in a happy atmosphere without torture, violence and crime.

All consequences are available, the state must inevitably provide protection to children. This commitment should be implemented in Indonesia's national law, namely the law on Child Protection Number 35 of 2014. However, with all the authority and power possessed, it can become the front guard in providing respect for the guarantee of children's rights in all aspects of life. The state must uphold the elimination of all forms of actions that endanger the future safety of the child. Children must be protected and protected regardless of their skin color, religion, ethnicity and gender and all social conditions of the child.

Based on the description above, several problems in this paper can be described as follows: First, how has the development of cases of crimes against children occurred in Indonesia in the past three years? Second, how important is the protection of children in the family, in schools and the environment to keep children away from violence and crime? Third, to what extent can the criminal justice system provide protection for children's rights as victims of threats of violence and crime related to the responsibility of the state in giving sanctions through the criminal justice system?

The method used in this research is juridical-normative, by literature study. In the literature, the source is legal materials. Legal material is anything that can be used or needed for the purpose of analyzing applicable laws. (H. Salim HS and Erlies Septiana Nurbani, 2014). The data collected is in question can be in the form of legislation or materials obtained from books, journals and other relevant materials. After the materials are obtained then analyzed to provide an overview of the problems studied. To have the picture of crime phenomena, secondary data is also used. 


\section{Discussion}

\subsection{Development of Crime Against Children}

The government sets every July 23 as a national children's day, as the excess of the importance of protection for children. Some countries in the world at certain moments also give serious attention to the lives of children. Various countries commemorate children's day internationally. June 1 is always commemorated by the international community as International Children's Day. Furthermore, on every November 20th, the world community will pay attention to the children with the commemoration of Universal Children 's Day. From the various commemorations of the children's day, it shows that significant attention given to the children as the part of world community. However, there are still parties who are not responsible for committing acts that are not commendable to children.

Many children are victims of violence and it happens everywhere. Not only at home, but also at school. The violence is not only physical, but also psychological. Various studies show that this really happened. For example, research on 2,600 elementary school students in Bandung City and Bandung Regency in 2015. This study showed that 70\% of children claimed to have had unpleasant actions during learning process, and it made the victims difficult to concentrate in learning (Saraswati, 2015). There is another survey of 300 respondents in secondary schools in the city of Semarang. The survey was conducted to find out the security when going to school, while at school and on the way home from school. The survey results show that $26.3 \%$ of respondents said that they felt insecure when ridiculed through shouting; $24.7 \%$ were harassed, $19 \%$ had been touched by breasts or buttocks; and 37.7\% had experienced bullying or fighting (Saraswati, 2015).

In research on Safe School and Gender-based violence in Middle School in Semarang City in terms of gender and level of education, there were male students (58 children) who were often beaten or invited to fight than girls (47 children). Female students (83 children) are more being crawled and pinched than male students (43 children) (Saraswati, 2015).

Thus, if it is seen, cases of violence committed by teachers on children can occur in the school environment. Ironic indeed, why does violence occur in the environment? Isn't the school supposed to be a place where children learn, and teachers become their protectors. At school sometimes the teacher with the reason of wanting to enforce discipline in children in the school environment is done in a way that is not commendable such as hitting children with objects that are actually inappropriate to do such as erasers, rulers and even punishing students by standing using one foot in front of the class. There were also those who were punished by running around the school grounds including children being told to sunbathe on the school grounds.

In 2016, in Kediri, East Java, 17 of the 58 underage children were identified as victims of rape, and of 58 children, currently only 5 children filed report to the authorities. In this incident initially the children who were victims were given anti-pregnancy drugs. Some of them have five months old pregnancy (Wijaya and Ananta, 2016).

Besides the cases of violence against children above, there are still many other cases experienced by children. It is still clear in our memories around 2015, boy Angeline aged (8) years
Jurnal Yustika Vol. 23 No. 01, Jul 2020

Page | 26

Legal Protection of the Rights of the Child Victims in

Indonesian Juvenile Criminal Justice

System

Oksidelfa Yanto Yoyon M Darusman Susanto Aria Dimas Harapan 
Jurnal Yustika

Vol. 23 No. 01, Jul 2020

Page | 27

Legal Protection of the Rights of the Child Victims in Indonesian Juvenile Criminal Justice System

Oksidelfa Yanto Yoyon M Darusman Susanto Aria Dimas Harapan old was raped and killed in his home on Jalan Sedap Malam Denpasar. Still in the same year, Princess Putri, a child around 9 years old, was found deceased in a cardboard box, in the Kalideres area, West Jakarta. The victim was suspected had experienced sexual violence before was killed.

Data reported by the Tangerang Selatan Raya daily newspaper on July 25, 2017 with the title "Violence of Children Continues to Increase", noted in 2016, there were 136 cases of violence against women and children in the city of South Tangerang. The number is detailed in several cases such as Domestic Violence (KDRT), dropping out of school, and sexual abuse. In 2017 up to July there were 40 cases.

Around May 2017, the Tambora Police arrested the perpetrators of child abuse. Three of the perpetrators persecuted Iqbal who was 4 years old. The poor child was pushed to the point of falling from the steps, then kicked in the stomach, even his head was banged against the wall. As a result, Iqbal suffered severe injuries and broken bones in his body.

Another case of crimes against children occurred in the Ciputat Police Sector jurisdiction, around March 2017. Where a scavenger molested two female children aged 6 years and 7 years. The two children were persuaded by the perpetrators with pocket money of Rp. 2,000, so you want to play into the rented room. In the rented room of the perpetrator, then the two children were molested.

At the end of 2017, it was revealed that an honorary teacher in Tangerang Banten committed sexual abuse against dozens of children aged 6 to 15 years in a hut. This case of sexual abuse against children occurred around April to November 2017. Initially children often stopped by the perpetrator's house. The victim was seduced by the perpetrator who claimed to have pellet science or semarmesem.

The last case that was not less miserable happened in Kudikan village, Sekaran Subdistrict, Lamongan Regency, East Java at the beginning of 2018. Ridwan, a 66 year old grandfather, conducted sexual intercourse with a 13-year-old junior high school student. The perpetrator did it in an empty house three times.

According to data from the Indonesian Child Protection Commission (KPAI) the number of victims and perpetrators of child protection cases in the period of 2014 to 2017 amounted to 1137 (men) and 778 (women). The complaints to KPAI between 2014 and 2017 are as follows; In 2014 the number of complaints was 322 cases, in 2015 there were 463 cases, in 2016 there were 587 cases and in 2017 there was a decline from 2016 as many as 514. The total complaints filed at the KPAI were 1886 complaints.

The cases of children above are still added to the number of children who are forced to work to help parents in fulfilling the family economy. Even worse, children are used as a source of money for parents and those who control children. So many parents impose the will and desire that children want to follow what parents want. In the traffic light corners on a big city street, we easily find a child who follows his parents begging. Around us, very many parents have the heart to force their children to take part in various kinds of tutoring, all of which eliminate the children's rights to play. Even though psychologically, children need play time so that they can express themselves freely. 
Listening to cases of violence and crime against children above, is clearly contrary to religious teachings. In Islamic teachings also explained that children are entrusted from Allah SWT to every desired human being. Islam gives a very noble appreciation to children in a family. There is no reason not to take good care of children. Indeed, there will be accountability on the last day for anyone who is given the mandate to care for children.

Whoever he is and where the person is, must prioritize the rights of the child, so as not to be disturbed by other irresponsible parties. He and wherever the person is located must provide protection for the rights of the child. Cases of violence and crimes against children's rights can be eliminated or avoided. Allah SWT condemns every act that does not respect human rights, such as torturing and even killing children. Torture, violence and even murder of children are prohibited in religious teachings, specifically Islam, this has been opposed since time immemorial, even since the time of Jahiliyyah. This is confirmed in the word of Allah SWT namely; "Whoever kills the soul of a human is not because of murder and not because of making damage on the earth, then he seems to kill all humans, and whoever saves the soul of a human being as if he saved all humans" (Qur'an, 32) Children's rights as a community must be given fairly according to existing law. Because substantially, justice resides and stretches in a deepest niche from the space of people's legal appreciation. This is where the substance of justice is formed, residing and stretching. (Bakir, 2015).

If you look at the history of the development of Islam there are actually so many events that illustrate the existence of partiality and concern for Islam over children's rights. In an exemplary story of the Prophet Muhammad the Prophet Muhammad, it has been shown how the Prophet Muhammad extended his prostration when the Prophet's grandson Husain rode the shoulders of the Prophet. At that time the community thought something had happened to the Prophet. But Rasulullah SAW explained to the public that, "My son (my grandson) has made me a mount, so I do not like to disturb his pleasure until he is satisfied,". Even Rasullulah SAW will shorten his prayer recitation when he hears the cry of a child, even though the Prophet SAW intended to extend his reading. But when suddenly heard the cry of a child. Then the Prophet SAW immediately shortened the prayer recitation. This was done by Rasullulah SAW because he understood the feelings of his mother (who had become a makmum) who was certainly disturbed by the crying of his child.

For this reason, in Islamic law the protection of children is included in the process of caring for young children, both men and women. Keeping from something that can hurt and damage it, educate the body, spirit and mind to be able to be independent and face life and assume responsibility (Hafsah, 2016). 


\subsection{The Importance of Child Protection}

Family is the most comfortable place for children to take refuge. From that, the role of the

Jurnal Yustika

Vol. 23 No. 01, Jul 2020

Page | 29

Legal Protection of the Rights of the Child Victims in Indonesian Juvenile Criminal Justice System

Oksidelfa Yanto Yoyon M Darusman Susanto Aria Dimas Harapan family becomes very important of children development. For children later when there is a problem can run to the family to talk about what they feel. The family in this case is of course the mother and father's parents. Mother and father are the smallest neighborhoods owned by children other than brothers and sisters. In the view of religion, family is the most important factor in shaping a person's personality and character.

Family is the basic unit of society, so it must be strengthened. The main responsibility for protecting, educating, and developing children lies with the family. All community institutions must respect children's rights and ensure the welfare of children and provide appropriate assistance to parents and families. (Kordi, 2013).

With the assistance and attention of the closest parents and siblings will make the child get attention and affection, and this will affect the child's psychological development towards a positive direction. Especially nowadays the technological development is so rapid. Children are so easily affected by various content that exists in cyberspace, which sometimes poses a danger to children.

Besides the role of parents, something that is not less important is the role of teachers in schools. Because children in addition to having time at home with family or parents, they will spend time in a place to study like school. Inevitably, when school children will meet with many people around him. The people around him have characters and traits that are different from each other. With the many differences, it will obviously have an impact on the development of the soul of the cyan, both positive and negative. For this reason, the role of the teacher is very important here.

Teachers are an important factor in achieving educational goals, because as an educator, the teacher is a facilitator, motivator, and inspiration for the formation of competencies and personal students. As an educator, teachers not only teach knowledge to students but also strive for how that knowledge becomes meaningful, for example by introducing local culture that is close to students (Yanda, 2017). The introduction of local culture can be carried out by the tutor teacher, so that the children of the students can get to know their culture and ensure good and correct child interaction.

In addition to the role of parents in the family and teacher environment in the school environment, what is equally important is the environment around the children living. The neighborhood is also an important factor, because in addition to children interacting with friends in school to spend time, children will also communicate with the environment in which their home is located. Many of us see examples of cases, children are affected by smoking, liquor, drugs and even promiscuity. Many children then go wrong and fall into negative things because they are wrong in choosing to hang out. If this is not a concern, then it is not wrong then the children who will become the foundation of hope for the future of this nation at stake will be a broken child with all his moral depravity. 
From that, the role of all parties must be put forward, parents, the government, even the RT head, RW chairman and community and religious leaders are very much needed for their role to keep children from environmental influences that will damage the brain and soul. Public responsibility is contained in the Child Protection Act No. 23 of 2002 as amended by Law Number 35 of 2014 concerning Amendments to Law Number 23 of 2002 concerning Child Protection. The second provision of the Child Protection Act above actually confirms that there is a responsibility of parents, families and the community towards child protection carried out through the activities of the community's role in the implementation of child protection.

\subsection{Juvenile Criminal Justice System and Protection of the Rights of Children as Victims}

Enforcement of criminal law is identical to the criminal justice system or the Criminal Justice System, which is essentially a criminal law enforcement system and identical with the judicial power system in the field of criminal law. As a system, the law enforcement system or judicial system is seen as an integral part of a variety of sub-systems or components, namely legal substance, legal structure, and legal culture. (Utomo \& Nadriana, 2014).

Seeing the phenomenon of violence and crime experienced by children, inevitably the law must be truly functioned. Especially criminal law. The function of criminal law to fight crimes against children's rights is a major factor in the success of the criminal justice system. Because crime will become rampant if the law is silent in the sense that it does not play its function. To be able to function criminal law as a protector of the community, integrity and compliance of law enforcement officers is needed in carrying out the law in a professional manner in accordance with the principle of legality or in accordance with the provisions of the applicable legislation.

The compliance of law enforcement officers with respect to the principle of legality is intended to ensure that every person is protected from violence, injustice, legal certainty, and equality before the law. In this way the law can be enforced. Because law enforcement does not violate the objectives of the law itself, namely protecting the rights of individuals and communities (LBH Jakarta, 2017). Without enforcement, the law is nothing. What gives meaning to the law are law enforcement officials and the community. (Muladi, 2009). Searching for laws in regulations is finding the meaning and values contained in the rules and not just reading them flatly. Law is not a telephone book that only lists rules and articles, but something that is full of meaning and value. ((Fanani, 2016).

When individual rights are not protected, the efforts of justice seekers whom the community desires are useless. Though the creation of justice is one of the tasks of the state, and in that context the judge becomes the representation of the state. Future expectations that judges in Indonesia will play a greater role in law enforcement in Indonesia will be a necessity because in practices in countries with civil law traditions there is also a tendency to increase the role of judges, if indeed there should be a shift in the role of legislation power which emphasizes the role of the legislature in the formation of law, towards the role of the judiciary power in the formation of law (Samekto, 2017). 
Jurnal Yustika

Vol. 23 No. 01, Jul 2020

Page | 31

Legal Protection of the Rights of the Child Victims in Indonesian Juvenile Criminal Justice System

Oksidelfa Yanto Yoyon M Darusman Susanto Aria Dimas Harapan
In addition to the above, the integrity of the legal apparatus will also be determined to what extent the law enforcement apparatus is able to educate the public with various information and information related to the existence of applicable laws in the community, so that the public becomes aware of the positive laws that apply. Giving information widely to the public is not just so that they know the legal regulations, but more than that, that is to make the community obedient and obedient to the law (Manan, 2013).

Associated with crimes against children, the law must be carried out in the context of child protection by the legal apparatus in accordance with the principle of legality, meaning that it is in accordance with the provisions of existing laws. The state must provide protection to children. Children must be protected without violence around them.

In effort to provide protection for children's rights both before and as victims, the state is the key to being able to provide such protection. When the state does not provide protection for children, the government has committed violations of Human Rights (HAM) as stipulated in Law No. 39 of 1999. In addition, violations of children's rights can be a very big barrier to the survival and development of children, because children who experience violence, exploitation, neglect and other mistreatment will experience risks, such as shorter lives, having poor mental and physical health, experiencing problems related to education (including dropping out of school), having poor skills as people old, homeless, expelled from his place of residence and has no home. For this reason, protection measures will have positive implications if the protection is successful, and in the end, it will increase the chances of children to grow physically, mentally, confidently, and have self-esteem (Saraswati, 2015).

In the context of child crime, there are laws governing child protection. Law No. 35 of 2014 concerning Child Protection explains the purpose of child protection, namely, to provide protection for Indonesian children from all forms of discrimination and violence. Moreover, Law Number 35 of 2014 has added to the definition of violence that was not previously contained in Law Number 23 of 2002.

Article 21 of Law Number 35 Year 2014 concerning Amendments to Law Number 23 Year 2002 concerning Child Protection explains that the state, government, and regional government are obliged and responsible to respect and guarantee the rights of every child. In addition, the Article also explains that the government is also not justified in distinguishing the name of religion, ethnicity, race, class, gender, ethnicity, culture and language, children's legal status, order of birth and physical and / or mental condition.

Looking at the article above, it looks so great that it is the responsibility of the state in efforts to provide protection for children. The obligation of the state to protect children from various types of crimes that befall them is a necessity that can no longer be bargained for. The state must be able to criminalize perpetrators of crimes against children. Because the perpetrator of a crime against a child has legal responsibility, especially criminal law for all acts he committed.

A person can only be convicted of guilty of a crime in the form of an offense, which is against the law and carried out by mistake. If this is fulfilled, a person can be convicted, but in several Articles of the general section of the Criminal Code (KUHP), lawmakers open the 
possibility to expand the participation of people who commit acts in several ways. Expansion of incrimination means that although not all elements of offense are fulfilled, sometimes there are also criminal acts. Thus, if there is an error, then the criminal act must be held accountable. In the criminal justice system, accountability for an error is usually directed at the person who made it.

The criminal responsibility of the maker arises when there is a relationship between the mind's inner attitude and the actions, he performs along with the normative elements contained in the formulation of a criminal act. The relationship in question is called error (Chazawi, 2016). The consequence is that the ability to be responsible is an element of crime, if there is no ability to be responsible, then there is no crime. (Prasetyo, 2013).

However, in the Anglo-Saxon countries the principle that is generally recognized is that for the existence of criminal liability is the necessity for mistakes, this is known as the principle of "mens rea". In this principle, it is explained that the person involved cannot see whether someone has committed an act that is contrary to the law. (Arbijoto, 2014).

In simple terms the criminal justice system is a process carried out by the state against people who violate criminal law. This process began with the police, prosecutors, and finally the court. The criminal justice system does not only cover one institution but is closely related to several state institutions. So that the work of one law enforcement officer will have an impact on the workload of other law enforcement officers. The law enforcers in the criminal justice system are integrated and cannot be separated (Hiariej, 2013)

Police, for example, as part of the criminal justice system based on Law Number 2 of 2002 concerning the Republic of Indonesia police must work pro-actively to receive complaints from related parties, such as the families of victims or people who witnessed violence or crimes against children. Or the police must also be pro-active in conducting investigations into the occurrence of crimes against ana. Likewise with prosecutors, as part of the criminal justice system according to Law Number 16 of 2014 concerning the Prosecutor's Office of the Republic of Indonesia and based on investigation reports prepared by police investigators, the prosecutor must be able to prove before the judge that the perpetrator of a crime against a child deserves punishment. The duty of the prosecutor is to prove the guilt or innocence of a suspect who is brought to court in accordance with the available evidence.

In the trial process, evidence is something that is very important function. Its existence to determine the outcome of a decision in a trial is crucial. In the process of proof in the trial it is closely related to the evidence (Mertokusumo, 2009).

Philosophically, proof is in the framework of assisting judges in deciding every case, both civil and criminal cases, so that the decisions handed down to justice seekers give a sense of justice (justice) (rechtzakerheid) and benefit (doelmatigheid) for them (HS and Nurbani, 2016).

Issued a new child protection law and later adopted the notion of violence against children, indicating that the state must no longer play games in protesting the rights of children. Law must provide justice to children. Because law is a tool to achieve justice and social change, if the law is only understood narrowly, then it is no different if the law is only a fence, and the legal profession 
Jurnal Yustika

Vol. 23 No. 01, Jul 2020

Page | 33

Legal Protection of the Rights of the Child Victims in Indonesian Juvenile Criminal Justice System

Oksidelfa Yanto Yoyon M Darusman Susanto Aria Dimas Harapan is nothing more than lawyers or fence builders; summum ius, summa iniura! Justice is only understood as procedural and legal justice (Salam, 2015).

From the description above and related to cases of crimes against children, the case of neglecting children's rights will be eradicated or reduced if the law is enforced. The final process in the court by giving the heaviest punishment to the perpetrators of violence or crime against children is a form of law enforcement efforts. Based on Law Number 48 of 2009 concerning Judicial Power, judges may not refuse to examine and try cases. After that with all kinds of considerations, the judge decided the case according to the sense of justice of the community. For this reason, it should be realized that every court decision must fulfill the elements of justice by upholding equality before the law and presumption of innocence.

If a court ruling upholds the principles of equality before the law and the presumption of innocence, it can be said that the decision has a human dimension. This is due to the two principles of equality before the law and the presumption of innocence containing the values of Human Rights (HAM). These human rights values must be protected and considered by law enforcers, especially judges who are authorized to decide cases (Nugroho, 2012).

Judges as part of judicial organizers in the criminal justice system, have an obligation to implement and implement criminal law properly in every decision. This is one way to overcome crime. Efforts to make good criminal law regulations cannot be separated from the objectives of crime prevention (Hikmawati, 2014).

Crime prevention can only be done by the government. The government in this case law enforcement officers must carry out their duties and responsibilities based on existing laws. In carrying out its duties and authorities according to responsibilities, the government adheres to three indicators, namely: 1) Government actions/actions in accordance with the law; 2) Effective supervision system; and 3) Executive and legislative balance. Indicators of government actions/ actions in accordance with the law want to measure the practices of the government (central/ regional) that are in accordance with the law through the performance and behavior of officials indicated or proven guilty of illegal acts (Ramiyanto, 2015).

If the government or legal apparatus does not implement the law properly for the benefit of humanity, then the state has denied legal and human rights norms. In a human rights perspective if it is associated with a criminal case examination process, this can be seen in the appreciation, practice and implementation of human rights, among others, contained in the procedural law, namely the Criminal Procedure Code (KUHAP). This KUHAP then describes the rights and obligations to uphold justice that should not be abandoned by every citizen, every organizer, every state institution either in the center or in the region (Sawitri, 2011).

Finally, the police, prosecutors, and judges as part of the legal apparatus as instruments of the criminal justice system in Indonesia play a role in ending or minimally reducing crimes against children by giving very severe penalties. The prevention of crime against children must be carried out through an integrated criminal justice system between the police, prosecutors and the judiciary and community institutions. With the existing criminal justice system, it is expected 
that the increase in crimes against children will end or be minimized, so that children's rights can be protected.

Jurnal Yustika Vol. 23 No. 01, Jul 2020

Page | 34

Legal Protection of the Rights of the Child Victims in society from physical, psychological, and sexual violence. In the context of a responsibility of the state in the protection of children, it is stated in the Child Protection Act. This is reinforced by the affirmation of criminal sanctions to anyone who intentionally or unintentionally acts that violate children's rights. If the state does not provide protection to children. So, the state committed violations of law and human rights violations because it has allowed children to be persecuted or persecuted with very cruel treatment. For that protection of children is something very important to be done by the state.

Police, prosecutors, and judges as legal implementers in the Indonesian criminal justice system must provide strict and severe punishment to perpetrators of violence and crimes against children. Because crimes for children's rights are highly organized crimes, which can involve many parties. Whoever and wherever the perpetrator is, accountability must be requested for all actions in accordance with the child protection law and the child criminal justice system law. Both in Indonesia and outside the territory of Indonesia.

\section{References}

$\underline{\text { Books }}$

Bakir, H, (2015), Filsafat Hukum, Tema-Tema Fundamental Keadilan dari Sisi Ajaran Fiat Justitia Ruat Caelum, Yogyakarta, Pustaka Pelajar.

Chazawi, A, (2016), Tindak Pidana Pornografi, Jakarta, Sinar Grafika.

Fanani, AZ, (2015), Pembaharuan Hukum Sengketa Hak Asuh Anak Di Indonesia, Yogyakarta, UII Press

Hiariej, E, (2013), Beberapa Catatan RUU KUHAP dan Hakim Pemeriksa Pendahuluan Dalam Konteks Sistem Peradilan Pidana Terpadu, Dalam Problematika Pembaharuan Hukum Pidana Nasional, Jakarta, Komisi Hukum Nasional RI.

H. HS Salim \& Nurbani ES, (2016), Penerapan Teori Hukum pada Penelitian Disertasi dan Tesis, Buku Ketiga, Jakarta, Rajawali Pers.

K. Kordi, MGH, (2013), HAM Tentang Kewarganegaraan, Pengungsi, Keluarga E Perempuan, Kompilasi Instrumen HAM Nasional dan Internasional, Yogyakarta, Graha Ilmu.

Manan, A, (2013), Aspek-Aspek Pengubah Hukum, Cetakan ke-4, Jakarta, Kencana Prenada Media Group.

Muladi, (2009), Hak Asasi Manusia Hakekat, Konsep dan Implikasinya dalam Perspektif Hukum dan Masyarakat, Bandung, Refika Aditama.

Mertokusumo, S, (2009), Hukum Acara Perdata Indonesia, Yogyakarta, Liberty.

Prakoso, A, (2016), Hukum Perlindungan Anak, Yogyakarta, LaksBang PRESSindo.

Prasetyo, A, (2013), Hukum Pidana, Jakarta: PT Raja Grafindo Persada, 2013.

Saraswati, R, (2015), Hukum Perlindungan Anak di Indonesia, Catakan II, Bandung, PT Citra Aditya Bakti.

Salam, S, (2015), Mendobrak Pendidikan Tinggi Hukum, Yogyakarta, Thafamedia.
Indonesian Juvenile Criminal Justice

System

Oksidelfa Yanto Yoyon M Darusman

Susanto

Aria Dimas Harapan 
Utomo L.St \& Nadriana L, (2014), Penerapan Hukum Pidana Kini dan Masa Mendatang, Yogyakarta, Genta Publishing.

Wijaya Andika \& Ananta WP, (2016), Darurat Kejahatan Seksual, Cetakan Pertama, Jakarta, Sinar

\section{Grafika.}

Vol. 23 No. 01, Jul 2020

Page | 35 Legal Protection of the Rights of the Child Victims in Indonesian Juvenile Criminal Justice System

\section{Oksidelfa Yanto} Yoyon M Darusman Susanto Aria Dimas Harapan

\section{Journal}

Arbijoto, (2014). "Subjek Hukum Tindak Pidana Korupsi Teori dan Praktek Pelaksanaannya", Jurnal Hukum Pepakem, Volume 1 Nomor 2, Oktober 2014.

Hafsah, (2016). "Kajian Perlindungan Hak Pendidikan dan Agama Anak Dalam Keluarga Muslim di Kota Medan", Jurnal Ahkam, Vol. XVI No. 2, Juli.

Hikmawati, P. (2014). "Politik Hukum Pidana Pemberian Penangguhan Penahanan Dalam Pemeriksaan Perkara", Jurnal Negara Hukum: Membangun Hukum untuk Keadilan dan Kesejahteraan, Vol. 5 No. 1, Juni.

Nugroho, W, (2012). “Disparitas Hukuman Dalam Perkara Pidana Pencurian Dengan Pemberatan", Jurnal Yudisial, Vol. 5 No. 3 Desember.

Ramiyanto, (2015). "Sah atau Tidaknya Penetapan tersangka Sebagai Objek Gugatan Praperadilan", Jurnal Yudisia, Vol. 8 No. 2 Agustus.

Samekto, A, FX, (2017). “Tantangan Hakim di Indonesia: Dari Penjaga Kepastian Hukum Menuju Pencipta Keadilan Berdasarkan Pancasila", Jurnal Ketatanegaraan, Volume: 004/September.

Sawitri, HW, (2011). “Pembantaran Penahanan Terhadap Tersangka Dalam Perspektif Hak Asasi Manusia", Jurnal Dinamika Hukum, Vol. 11 No. 1 Januari.

\section{Laws and Regulations}

Laws Number 16 of 2004 concerning The Prosecution of Republic of Indonesia.

Laws Number 8of 1981concerning Indonesian Criminal Procedure Code.

Laws Number 1 of 1946 concerning Criminal Code.

Laws Number 35 of 2014 concerning Child Protection.

Laws Number 23 of 2002 concerning Child Protection.

Laws Number 39 of 1999 concerning Human Rights.

\section{Prosiding}

Yanda, DP, (2017). “Peranan Guru Bahasa Sebagai Agen Pembelajaran Untuk Meningkatkan Pengetahuan dan Kemampuan Berbahasa Siswa Melalui Pembelajaran Berbasis Budaya Di Sekolah Menengah", Proceeding, "Intercultural Communication through Language, Literature, and Arts", Faculty of Languages And Arts Universitas Negeri Jakarta, May 1718.

Magazines

Alghiffari Aqsa, (2017). “Redupnya Api Reformasi”, Majalah Catatan Akhir Tahun LBH Jakarta. 